Check for updates

Cite this: RSC Adv., 2019, 9, 37926

\title{
A naphthoquinone based colorimetric probe for real-time naked eye detection of biologically important anions including cyanide ions in tap water: experimental and theoretical studies
}

\begin{abstract}
Johannes Naimhwaka and Veikko Uahengo (iD *
A naphthoquinone based colorimetric sensor $(\mathrm{N})$ bearing hydrazone receptors in aqueous media was developed and its recognition properties towards biologically important anions in DMSO-water mixture (9:1) were investigated using spectroscopic methods. The hydrazone based receptors showed selectivity towards anions $\left(\mathrm{F}^{-}, \mathrm{OH}^{-}, \mathrm{CN}^{-}\right.$and $\left.\mathrm{AcO}^{-}\right)$, through naked eye observable colour changes, from green to light blue $\left(\mathrm{F}^{-}, \mathrm{CN}^{-}\right.$and $\left.\mathrm{AcO}^{-}\right)$and violet $\left(\mathrm{OH}^{-}\right)$. The colour changes were concomitant with spectral changes. The sensor could also detect the presence of fluoride ions in commercially available toothpastes, through remarkable colour and spectral changes. In addition, test paper strips prepared from $\mathrm{N}$ were able to detect the presence of cyanide $(\mathrm{KCN})$ and hydroxide $(\mathrm{NaOH})$ in tap water. The study was complimented by density functional theory computations to have more insight in the interaction between $\mathrm{N}$ and the anions.
\end{abstract}

Received 6th August 2019

Accepted 14th November 2019

DOI: 10.1039/c9ra06116a

rsc.li/rsc-advances

\section{Introduction}

The development of sensors and receptors for anion detection has been receiving great attention in recent years, ${ }^{1-5}$ because of their extensive roles in the biological, chemical and environmental fields. ${ }^{6-12}$ This technique falls among other optical methods that are proving to be convenient for ion monitoring and detection. ${ }^{13-17}$ Colorimetric detection is mostly popular due to its naked eye detectable changes, achieved without resorting to expensive spectroscopic instruments. ${ }^{18-24}$ Thus, colorimetric sensors do offer several advantages over conventional instrumental methods such as atomic absorption spectroscopy, voltammetry, inductively coupled plasma emission, X-ray photoelectron spectroscopy or mass spectroscopy, due to their simplicity, high sensitivity and selectivity, perform real time-monitoring, cost effective, as well as their naked eye observable colour changes. ${ }^{25-32}$

Fluoride $\left(\mathrm{F}^{-}\right)$and acetate $\left(\mathrm{AcO}^{-}\right)$ions play a significant role in environmental and physiological processes. For instance, the presence acetate ion in physiological systems is mostly significant in acetyl coenzyme activities, and it is heavily used in the manufacturing industry for products such as dyes, plastics, paints and paper. ${ }^{33-36}$ On the other hand fluoride ion has been primarily used in the dental care industry and it can be applied in osteoporosis treatment. ${ }^{37,38}$ However, in excessive amounts it is greatly toxic to the biological tissue which can lead to

Department of Chemistry and Biochemistry, University of Namibia, 340 Mandume Ndemufayo Avenue, Windhoek, 9000, Namibia. E-mail: vuahengo@unam.na; Fax: +26461206 3465; Tel: +264612063465 fluorosis and osteosclerosis and cause many serious neurodegenerative diseases. ${ }^{39-42}$ Correspondingly, cyanide is one of the most toxic anions and the World Health Organization has set its maximum permissive level in drinking water at $1.9 \mu \mathrm{M}^{43-47}$ However, it is still indispensable in some industrial usage such as electroplating, synthesis of fine chemicals, plastic production and gold mining. ${ }^{48}$ Despite a huge number of anion sensors published in literature, there are very limited modulus which can detect cyanide ions, simultaneously with fluoride, acetate and hydroxide ions. Moreover, there is still a very huge gap in industry for practical applications of chemosensor modulus published in literature. Therefore, there is still a great need to develop more effective, cost effective, aqueous based and user friendly sensors, in order to continuously monitor the levels of these anions in different systems.

Herein, we report the synthesis of a remarkable napthoquinone based colorimetric sensor $\mathbf{N}$ (Scheme 1) with hydrazone derivative signaling units, and its application towards anion sensing. The design of $\mathbf{N}$ is based on the rich-in- $\pi$-electron aromatic framework which is potentially likely to result in an excellent sensor, especially when coupled with a powerful electron withdrawing group (EWG) of the nitro group $\left(-\mathrm{NO}_{2}\right)$, resulting in a moiety with strong electronic coupling, from the receptor to the reporting unit. Subsequently, $\mathbf{N}$ is found highly selective and sensitive to four anions being $\mathrm{F}^{-}, \mathrm{OH}^{-}, \mathrm{AcO}^{-}$and $\mathrm{CN}^{-}$in DMSO- $\mathrm{H}_{2} \mathrm{O}(9: 1)$ among several anions. The four anions induce significant changes, both in the absorption spectrum and colorimetric changes upon molar additions of the three anions to $\mathbf{N}$ in DMSO- $\mathrm{H}_{2} \mathrm{O}(9: 1)$. Furthermore, for 
practical applications, test papers were also prepared and used in samples, providing remarkable results, which were able to detect cyanide ion-contaminated tap water through colour changes. The sensor was also applied in real sample analysis of commercially available toothpastes (Colgate and Aqua-fresh) which are known to contain fluoride ions.

\section{Experimental section}

\subsection{Materials and apparatus}

All reagents and solvents were commercially available and of analytical grade. They were used without further purification unless stated. UV/vis spectroscopy was performed with PerkinElmer Lambda 35 spectrophotometer in a standard $3.0 \mathrm{ml}$ quartz cuvette with $1 \mathrm{~cm}$ path length. FT-IR spectra were obtained on a PerkinElmer Spectrum 100 FTIR spectrometer. ${ }^{1} \mathrm{H}$ NMR spectra were recorded on a Varian Mercury VX-300 MHz spectrometer in $d_{6}$-DMSO, steady state excitation and emission spectra were obtained on the Molecular Device spectraMax M2. Elemental analyses (C, H and N) were carried out on a PerkinElmer 240C analytical instrument. All the measurements were carried out at ambient temperature $\left(25^{\circ} \mathrm{C}\right)$.

\subsection{Synthesis of sensor $\mathbf{N}$}

The sensor ( $\mathbf{N}$ ) was synthesized according to Scheme 1, using the approach of green chemistry via a simple, low cost and onestep-reaction Schiff base condensation reaction. ${ }^{49-51}$ To the ethanol solution $(20 \mathrm{ml})$ of 2,4-dinitrophenylhydrazine (2 $\mathrm{mmol}$ ), while magnetically stirred, was charged with the ethanolic solution $(20 \mathrm{ml})$ containing about 1,4-napthoquinone (1 $\mathrm{mmol}$ ), drop-wise. The resulting solution mixture was catalyzed with $5 \mathrm{ml}$ of acetic acid and refluxed for $3 \mathrm{~h}$, which resulted in a light brown precipitate being formed. The product was filtered out while the solution was hot, and washed repeatedly with warm ethanol. The product was further recrystallized in ethanol to yield a light brown precipitate $(\mathbf{N})$ as outlined in Scheme 1. Yield: $43 \% .{ }^{1} \mathrm{H}$ NMR (300 MHz, DMSO- $\left.d_{6}\right) \delta 9.92(\mathrm{~s}, \mathrm{NH}), 8.79(\mathrm{~d}$, $J=2.7 \mathrm{~Hz}, 2 \mathrm{H}, \mathrm{ArNO}_{2}$ ), $8.22\left(\mathrm{dd}, J=9.7,2.7 \mathrm{~Hz}, 2 \mathrm{H}, \mathrm{ArNO}_{2}\right), 7.92$ (dd, $J=5.8,3.3 \mathrm{~Hz}, 4 \mathrm{H}, \mathrm{Ar}$ ), 7.67 (d, $J=9.7 \mathrm{~Hz}, 2 \mathrm{H}, \mathrm{Ar}$ ). Elemental analysis calcd (\%) for $\mathrm{C}_{22} \mathrm{H}_{14} \mathrm{~N}_{8} \mathrm{O}_{8}$ : C, 50.97; $\mathrm{H}$, 2.72; N, 21.62; O, 24.69; found: C, 51.27; H, 2.54; N, 20.93; O, 22.91. The $\mathrm{UV}$-vis spectrum of $\mathbf{N}$ exhibits a band at $357 \mathrm{~nm}(\varepsilon=$ $\left.1.74 \times 10^{4} \mathrm{M}^{-1} \mathrm{~cm}^{-1}\right)$.

\subsection{General procedures for UV-vis and fluorescence experiments}

All UV-vis spectra were recorded in DMSO- $\mathrm{H}_{2} \mathrm{O}$ on a PerkinElmer Lambda 35 spectrometer after the addition of

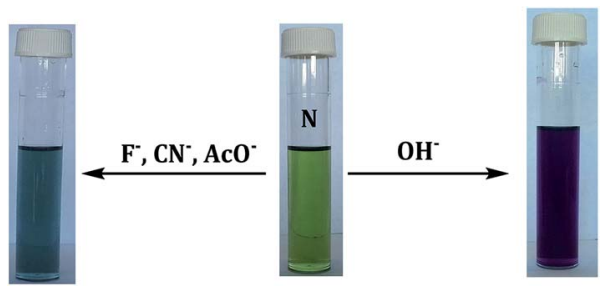

Fig. 1 Visual colour changes of $\mathrm{N}$ in $\mathrm{DMSO}-\mathrm{H}_{2} \mathrm{O}\left(1 \times 10^{-5} \mathrm{M}\right)$, upon addition of 3 equiv. of $\mathrm{CN}^{-}, \mathrm{F}^{-}, \mathrm{AcO}^{-}$and $\mathrm{OH}^{-}$, respectively.

tetrabutylammonium salts while keeping the sensor $\mathbf{N}$ concentration constant $\left(1 \times 10^{-5} \mathrm{M}\right)$. Tetrabutylammonium salt (TBA) of anions $\left(\mathrm{F}^{-}, \mathrm{Cl}^{-}, \mathrm{Br}^{-}, \mathrm{I}^{-}, \mathrm{AcO}^{-}, \mathrm{H}_{2} \mathrm{PO}_{4}^{-}, \mathrm{ClO}_{4}{ }^{-}\right.$, $\mathrm{CN}^{-}$) were used for UV-vis experiments. Subsequently, all fluorescence spectra were recorded on a Molecular Devices SpectraMax M2 upon the addition of TBA salts while keeping the concentration of $\mathbf{N}$ constant $\left(1 \times 10^{-5} \mathrm{M}\right)$. TBA salts of anions $\left(\mathrm{F}^{-}, \mathrm{Cl}^{-}, \mathrm{Br}^{-}, \mathrm{OH}^{-}, \mathrm{I}^{-}, \mathrm{AcO}^{-}, \mathrm{H}_{2} \mathrm{PO}_{4}{ }^{-}, \mathrm{ClO}_{4}{ }^{-}, \mathrm{CN}^{-}\right)$were used for fluorescence experiments.

\section{Results and discussion}

\subsection{Colorimetric analysis of $\mathrm{N}$ with anions}

In order to establish whether there is any chemical interaction between $\mathbf{N}$ and all respective anions, a series of prepared anionic solutions $\left(1 \times 10^{-3} \mathrm{M}\right)$ in DMSO- $\mathrm{H}_{2} \mathrm{O}$ were added dropwise, each separately, to $3 \mathrm{ml}$ of $\mathbf{N}\left(1 \times 10^{-5} \mathrm{M}\right)$ in a similar solution (DMSO- $\left.\mathrm{H}_{2} \mathrm{O}\right)$, at room temperature. The resulting observations were recorded as indicated (Fig. 1). Upon dropwise addition of the $\mathrm{CN}^{-}, \mathrm{F}^{-}$and $\mathrm{AcO}^{-}$, all as tetrabutylammonium salts (TBA), a visible colour change was observed from the original colour of $\mathbf{N}$ (light-greenish) to light blue (Fig. 1). However, when the $\mathrm{OH}^{-}$(TBA) was added dropwise to the solution of $\mathbf{N}$, the colour changed to violet (Fig. 1). The intensities of colour depended on the concentration of the $\mathbf{N}$ in the solution, ranging from intense (high concentration) to relatively weaker or lighter colours at lower concentrations. Moreover, these anions are all electronegative in nature, which are likely to interact with electropositive protons $(-\mathrm{NH})$ in the structure, however, they all have different affinities towards $\mathbf{N}$ due to differences in association constants with the proton group in the structure (N), normally with $\mathrm{F}^{-}$strongly associated with the protons due to its smaller size and high electronegative than others. In contrast; other competitive anions such as $\mathrm{Cl}^{-}, \mathrm{Br}^{-}$, $\mathrm{I}^{-}, \mathrm{H}_{2} \mathrm{PO}_{4}{ }^{-}$, and $\mathrm{ClO}_{4}{ }^{-}$were completely non-responsive as there were no significant colour changes observed upon their addition of each to the solution of $\mathbf{N}$.

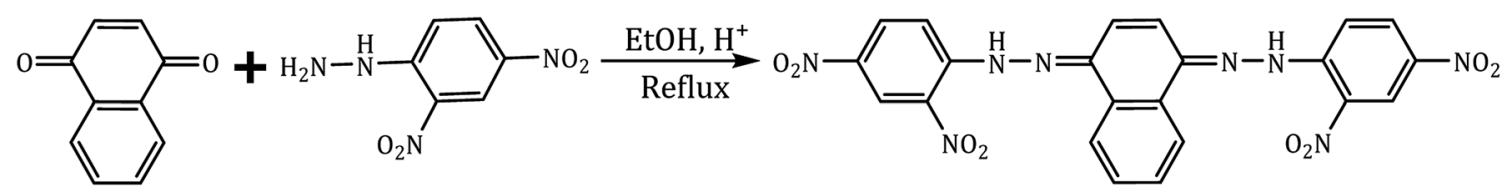

Scheme 1 Synthetic procedure of $\mathrm{N}$. 


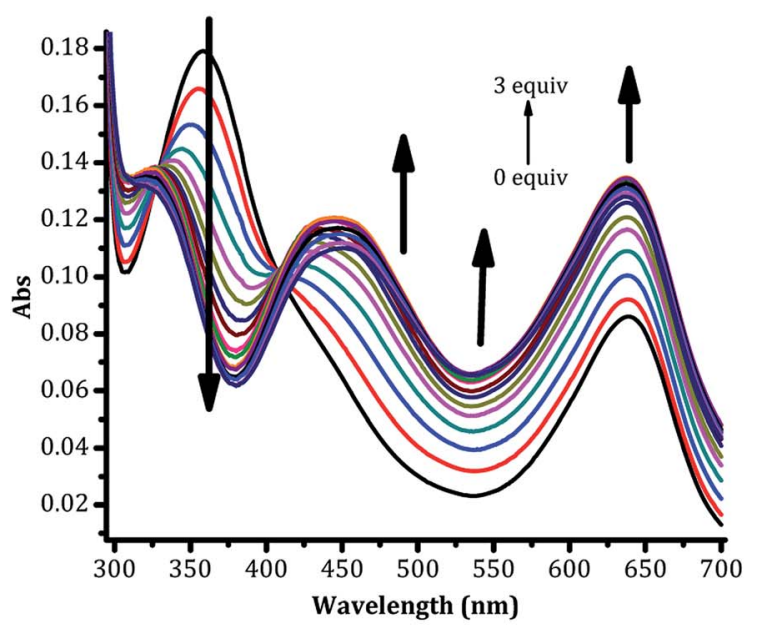

(a)

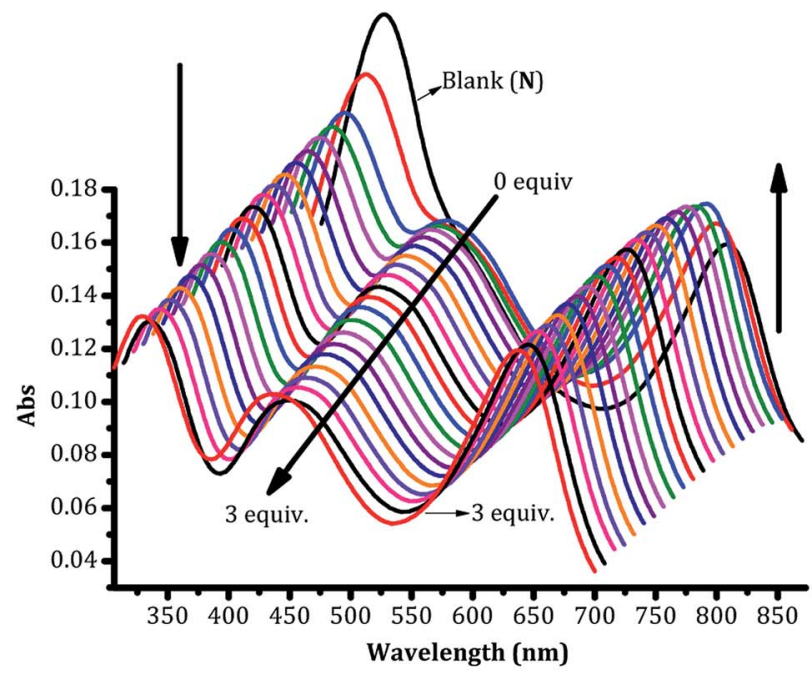

(b)

Fig. 2 UV-vis absorption spectra of $\mathrm{N}$ in DMSO- $\mathrm{H}_{2} \mathrm{O}\left(1 \times 10^{-5} \mathrm{M}\right)$ upon the molar addition (0-3 equiv.) of (a) $\mathrm{CN}^{-}$, (b) A 3-D plot of the spectra.

\subsection{UV-vis studies of $\mathbf{N}$}

The absorption spectra of $\mathbf{N}$ in DMSO- $\mathrm{H}_{2} \mathrm{O}$ were characterized by two prominent absorption bands at $356 \mathrm{~nm}$ and $637 \mathrm{~nm}$, attributed to internal-charge transfer (ICT) of the nitrophenyl groups and the naphthyl moiety in the middle, respectively. Moreover, $\mathbf{N}$ displayed a fluorescent emission in visible light region characterized by two weak vibronic peaks, with maxima at $416 \mathrm{~nm}$ and $438 \mathrm{~nm}$ respectively. The weakened emission is suspectedly attributed to the presence of electron withdrawing $\mathrm{NO}_{2}$ groups in the structure.

\subsection{Photophysical properties of $\mathrm{N}$ towards $\mathrm{CN}^{-}$and other anions}

UV-vis titrations were conducted in order to investigate spectra behaviors of $\mathbf{N}$ upon interacting with different anions $\left(\mathrm{F}^{-}, \mathrm{Cl}^{-}\right.$, $\mathrm{Br}^{-}, \mathrm{I}^{-}, \mathrm{AcO}^{-}, \mathrm{H}_{2} \mathrm{PO}_{4}{ }^{-}, \mathrm{ClO}_{4}{ }^{-}, \mathrm{CN}^{-}$) in DMSO- $\mathrm{H}_{2} \mathrm{O}$ and confirm the colorimetric activities observed in the section above. Subsequently, upon the molar addition of $\mathrm{CN}^{-}$to $\mathbf{N}$, a remarkable change in spectra activities were observed, where an initial absorption band at $356 \mathrm{~nm}$, due to the $\mathrm{n} \rightarrow \pi^{*}$ transitions, gradually decreased significantly, at the same time experiencing a hypsochromic shift, while the band at $637 \mathrm{~nm}$, attributed to $\pi$ $\rightarrow \pi^{*}$ transitions, increased in intensity (Fig. 2a), upon complexation with an incoming cyanide ions. Moreover, a new band centered at $445 \mathrm{~nm}$ appeared gradually with a bathochromic intensity increase. The isosbestic point observed is a clear indication of two species in one system at equilibrium. A 3-dimensional plot (Fig. 2b) of the titrations of $\mathbf{N}$ with $\mathrm{CN}^{-}$ clearly shows the variations of the spectra and their gradual shifts as explained above. The gradual spectral changes experienced with the molar additions of the cyanide ion, were complimentary with the colorimetric activities observed. The summary of spectral data is provided (Table 1) detailing the molar absorptivities (with and without the addition of $\mathrm{CN}^{-}$), the fluorescence quantum yield and the Stokes shift (the difference in wavelength of the band maxima of absorption and emission).

Accordingly, the Job plot (Fig. 3a) has given a clue that the interaction ratio between $\mathbf{N}$ and $\mathrm{CN}^{-}$is predominantly $1: 2$ ( $\mathbf{N}: 2 \mathrm{CN}$ ) with the possibility of fractional existence of a $1: 1$ interaction ratio, which is closely in agreement with theoretical prediction as shown (Fig. 4a), interacting through the hydrazone protons. The titration profile (Fig. $3 \mathrm{~b}$ ) of $\mathbf{N}$ with $\mathrm{CN}^{-}$is also in agreement with the Job plot results, as the interaction seemed to reach equilibrium upon the addition of 1 to 2 molars of the toxic anion. Furthermore, similar changes were also observed in UV-vis spectra of $\mathbf{N}$ upon molar additions of $\mathrm{F}^{-}$and $\mathrm{AcO}^{-}$(Fig. 5a and b). Nevertheless, the addition of $\mathrm{Cl}^{-}, \mathrm{Br}^{-}, \mathrm{I}^{-}$, $\mathrm{H}_{2} \mathrm{PO}_{4}{ }^{-}$and $\mathrm{ClO}_{4}{ }^{-}$, did not result in any significant response (Fig. 4b).

Job's plot has hinted that the binding ratio between $\mathbf{N}$ and the respective anions $\left(\mathrm{F}^{-}, \mathrm{OH}^{-}, \mathrm{AcO}^{-}\right.$and $\left.\mathrm{CN}^{-}\right)$is at $1: 2$, with anions binding via hydrogen bonding of the $-\mathrm{NH}$ group, well known with similar receptors. However, there exists a possibility

Table 1 Spectral data of $\mathrm{N}$ and interaction with $\mathrm{CN}^{-}$

\begin{tabular}{|c|c|c|c|c|c|c|}
\hline Sensor & $\begin{array}{l}\lambda_{\max }, \text { abs peaks }(\mathrm{nm}) \\
\text { without } \mathrm{CN}^{-}\end{array}$ & $\begin{array}{l}\varepsilon\left(\mathbf{M}^{-1} \mathrm{~cm}^{-1}\right) \\
\text { without } \mathrm{CN}^{-}\end{array}$ & $\begin{array}{l}\lambda_{\max }, \text { abs peaks }(\mathrm{nm}) \\
\left(\text { with } \mathrm{CN}^{-}\right)\end{array}$ & $\begin{array}{l}\varepsilon\left(\mathrm{M}^{-1} \mathrm{~cm}^{-1}\right) \\
\text { with } \mathrm{CN}^{-}\end{array}$ & $\begin{array}{l}\lambda_{\max }, \text { em }(\mathrm{nm}) \\
\text { with } \mathrm{CN}^{-}\left(\Phi_{\mathrm{F}}\right)\end{array}$ & $\begin{array}{l}\text { Stokes shift } \\
(\mathrm{nm})\end{array}$ \\
\hline $\mathbf{N}$ & $356 ; 637$ & $18000 ; 8700$ & $320 ; 637$ & $13300 ; 13600$ & $415 ; 436(0.58)$ & 79 \\
\hline
\end{tabular}




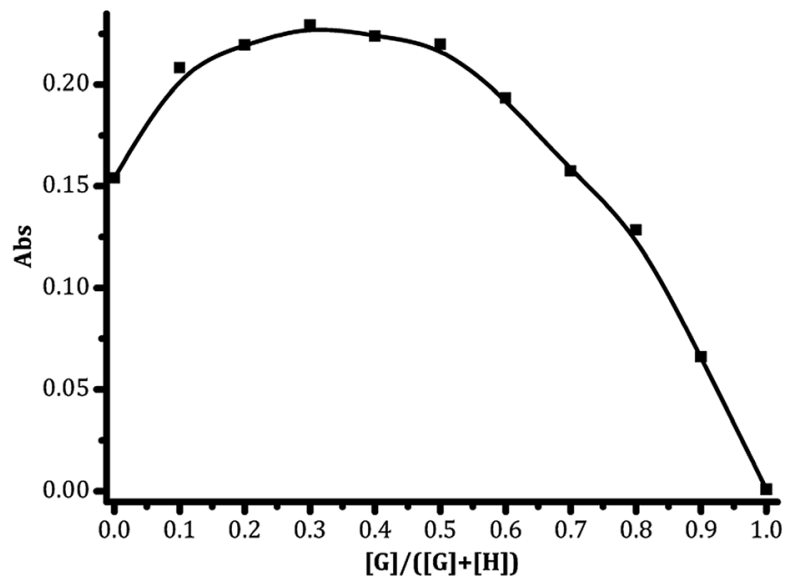

(a)

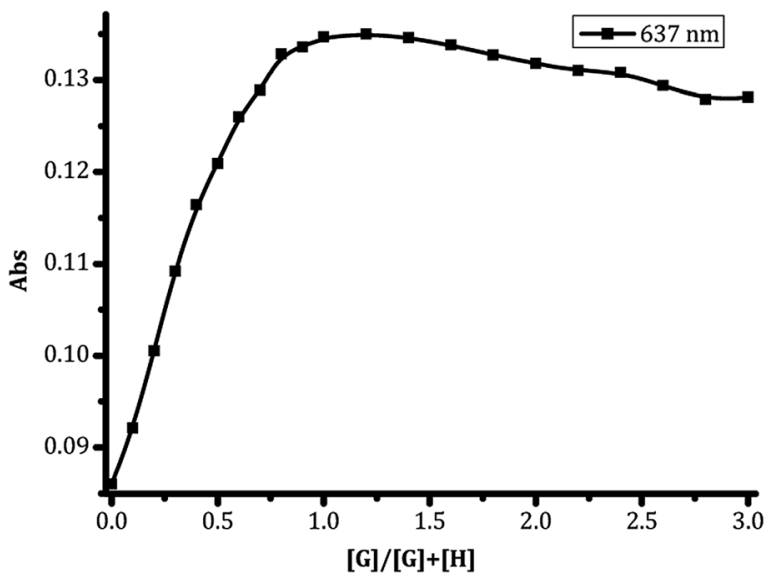

(b)

Fig. 3 (a) The Job plot and (b) titration profile, of $\mathrm{N}$ with $\mathrm{CN}^{-}$.

of deprotonation once excess anions are added, liberating the proton from the $-\mathrm{NH}$ group to form the HCN entity as shown (Scheme 2), leaving the imine group in a radical form. Thus, the proposed interaction mechanisms is based on hydrogen bonding through the -NH group, followed by deprotonation when an anion is in excess. The deprotonation mechanism is however taking place in sequences via intermediate steps, afore attaining the final structural conformation, which is kinetically and thermodynamically governed by the fundamental principles of the rates of chemical reactions.

\subsection{Photophysical properties of $\mathrm{N}$ towards $\mathrm{OH}^{-}$}

Moreover, the molar addition of $\mathrm{OH}^{-}$to $\mathbf{N}$, resulted in another slightly different behavior from the above anions $\left(\mathrm{CN}^{-}, \mathrm{F}^{-}\right.$and $\mathrm{AcO}^{-}$), both in terms of colour (Fig. 1) and spectral changes (Fig. 7). The initial intense peak at $357 \mathrm{~nm}$ decreased in intensity with a hypsochromic shift effect (at $320 \mathrm{~nm}$ ), with a new peak simultaneously forming at $445 \mathrm{~nm}$ due to the complexation of $\mathbf{N}$ with $\mathrm{OH}^{-}$. While the peak at $637 \mathrm{~nm}$ has experienced increase in intensity, the isosbestic point at $408 \mathrm{~nm}$ clearly indicates that two species existed at equilibrium in one system. A better view of spectral changes upon the molar addition of $\mathrm{OH}^{-}$are displayed in the 3-dimensional plot (Fig. 7b), which clearly shows how individual spectrum varies with one another. The Job plot of $\mathbf{N}$ with $\mathrm{OH}^{-}$shows the admixture of possibly a $1: 1$ and $1: 2(\mathbf{N}: \mathrm{OH})$ or even more complex than this (Fig. 6), presumably due to the interaction nature of the hydroxide ions with $\mathbf{N}$, which is mainly not only through hydrogen bonding, but are also rich in hydrogen atoms $(\mathrm{OH})$. As a result, even the colorimetric activities (green to violet) observed were slightly different from other ions detected $\left(\mathrm{CN}^{-}\right.$, $\mathrm{F}^{-}, \mathrm{AcO}^{-}$), green to light blue (Fig. 1). Moreover, the titration profile (inset, Fig. 7a) clearly indicates the dynamics of the formation of the complexed $\mathbf{N}-\mathrm{OH}$ moiety, concomitant with the disappearance of $\mathbf{N}$. In Table 2, the summary of spectral data of $\mathbf{N}$ are provided detailing the absorption wavelengths and molar absorptivities (with and without the addition of $\mathrm{OH}^{-}$).

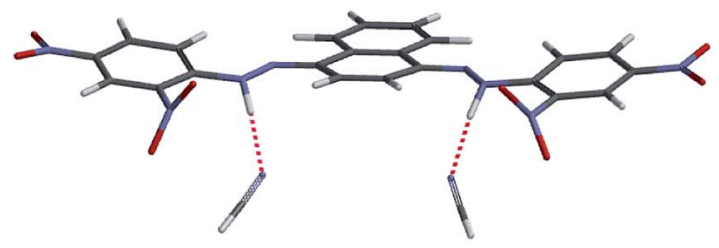

(a)

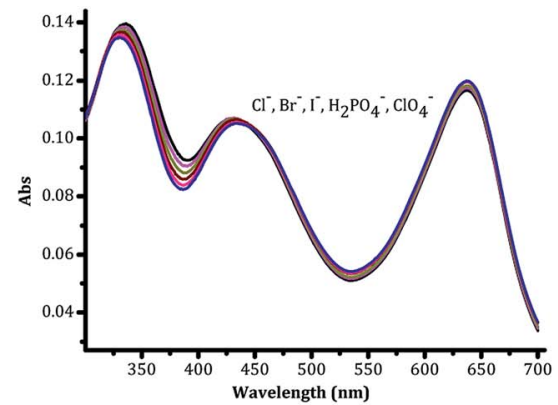

(b)

Fig. 4 The proposed binding mechanism of (a) $\mathrm{N}$ to $2 \mathrm{CN}^{-}(1: 2)$ and (b) titration spectra of other anions. 


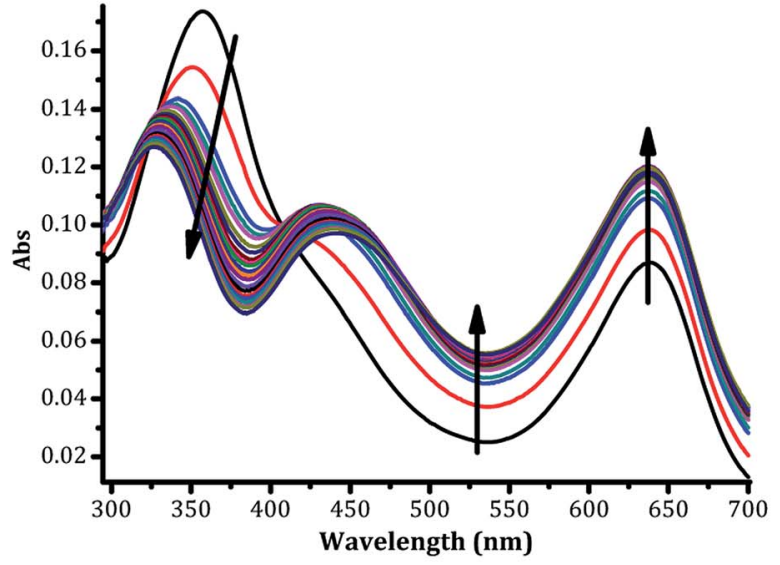

(a)

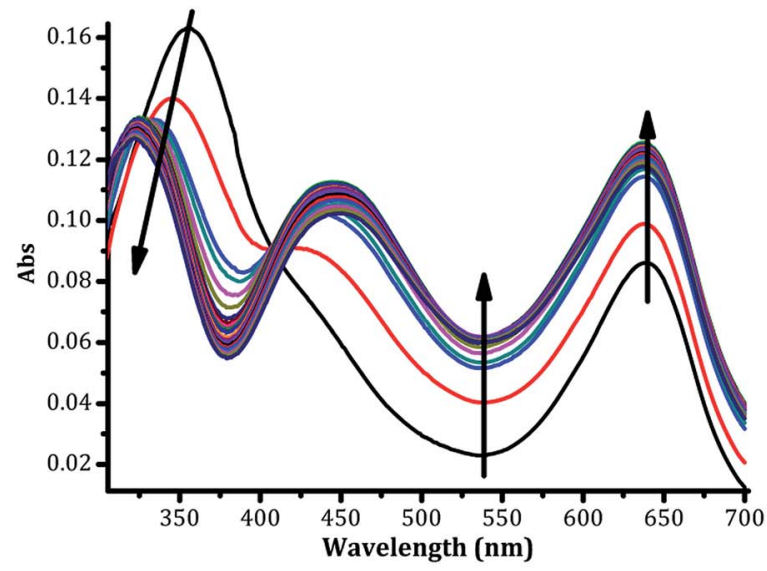

(b)

Fig. 5 The UV-vis titration spectra of $\mathrm{N}$ in $\mathrm{DMSO}-\mathrm{H}_{2} \mathrm{O}$ with 3 equiv. of (a) $\mathrm{AcO}^{-}$and (b) $\mathrm{F}^{-}$.

\subsection{Fluorescence studies of $\mathbf{N}$ upon interaction with anions $\left(\mathbf{C N}^{-}\right)$}

The fluorescence property of sensor $\mathbf{N}$ towards its selective anions was investigated in DMSO- $\mathrm{H}_{2} \mathrm{O}$ by fluorescent molar titrations. The free sensor $\mathbf{N}$ exhibits two emission maxima at $415 \mathrm{~nm}$ and $436 \mathrm{~nm}$ upon excitation at $400 \mathrm{~nm}$. However, when 0-3 equiv. of $\mathrm{CN}^{-}$(tetrabutylammonium cyanide) was added to the solution of $\mathbf{N}$, a concomitant increase in fluorescence intensity was observed (Fig. 8). The fluorescence intensity of $\mathbf{N}$ peaked at 17, however, when the molar addition of $\mathrm{CN}^{-}(0-3$ equiv.) was gradually introduced, there was a slight enhancement in the fluorescence intensity to about 40, ascribed to structural deprotonation of $\mathbf{N}$ (from $\mathbf{N H}-\mathrm{CN}$ to $\mathbf{N}^{-}+\mathrm{HCN}$ ), after which no matter how much of $\mathrm{CN}^{-}$was added afterward, no significant change could be observed. The molar addition using other anions did not induce any significant change in the emission intensity. Thus, the enhanced emissive properties of $\mathbf{N}$ may be ascribed to structural deprotonation (from $\mathrm{NH}-\mathrm{CN}$ to $\mathbf{N}^{-}+\mathrm{HCN}$ ) upon the addition of $\mathrm{CN}^{-}$, which is may not be the case upon adding any other anion.

The characteristics of the fluorescence enhancement are presided by the removal of the $\mathrm{n} \rightarrow \pi^{*}$ transitions which are normally known to mask the $\pi \rightarrow \pi^{*}$ transition, which are mainly responsible to the emission behaviors. This is another<smiles>N#CC1=CC(=NNc2ccc([N+](=O)[O-])cc2[N+](=O)[O-])c2ccccc2/C1=N\C1C=CC(=NNc2ccc([N+](=O)[O-])cc2[N+](=O)[O-])c2ccccc21</smiles>

Scheme 2 Proposed binding mechanism of $\mathrm{N}$ on interaction with anions $\left(\mathrm{CN}^{-}\right.$ion) in $\mathrm{DMSO}-\mathrm{H}_{2} \mathrm{O}$. 


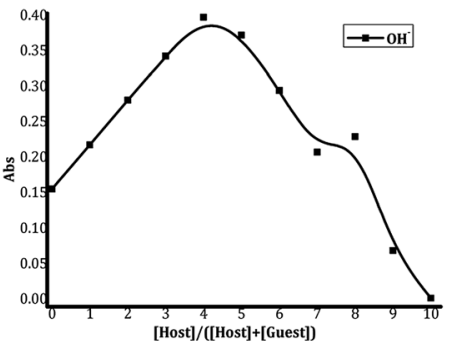

(a)

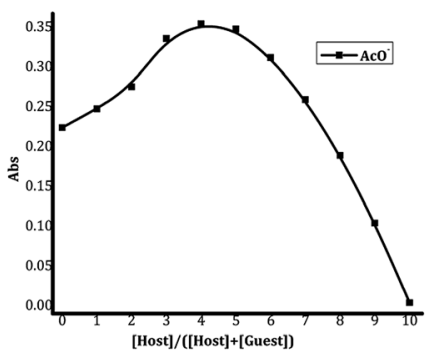

(b)

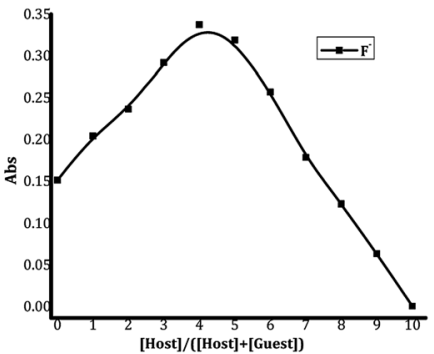

(c)

Fig. 6 The Job plot of $\mathrm{N}$ with (a) $\mathrm{OH}^{-}$, (b) $\mathrm{AcO}^{-}$and (c) $\mathrm{F}^{-}$in $\mathrm{DMSO}-\mathrm{H}_{2} \mathrm{O}$.

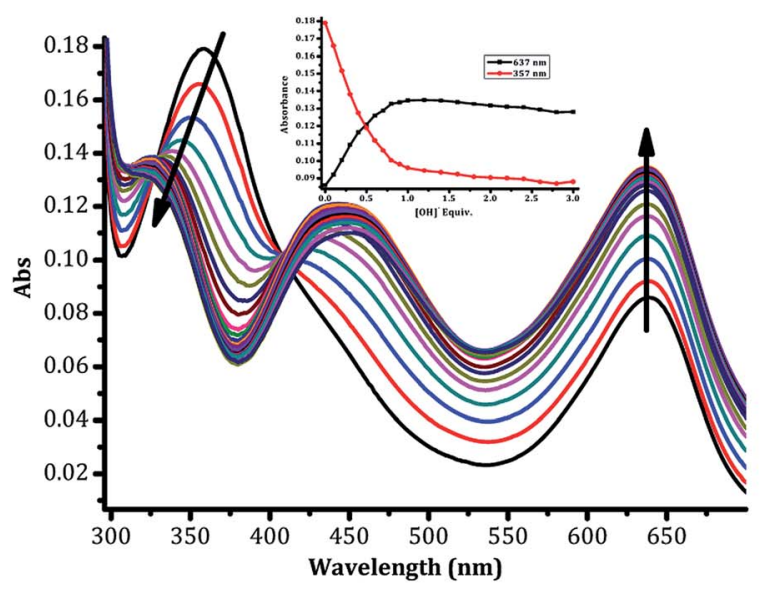

(a)

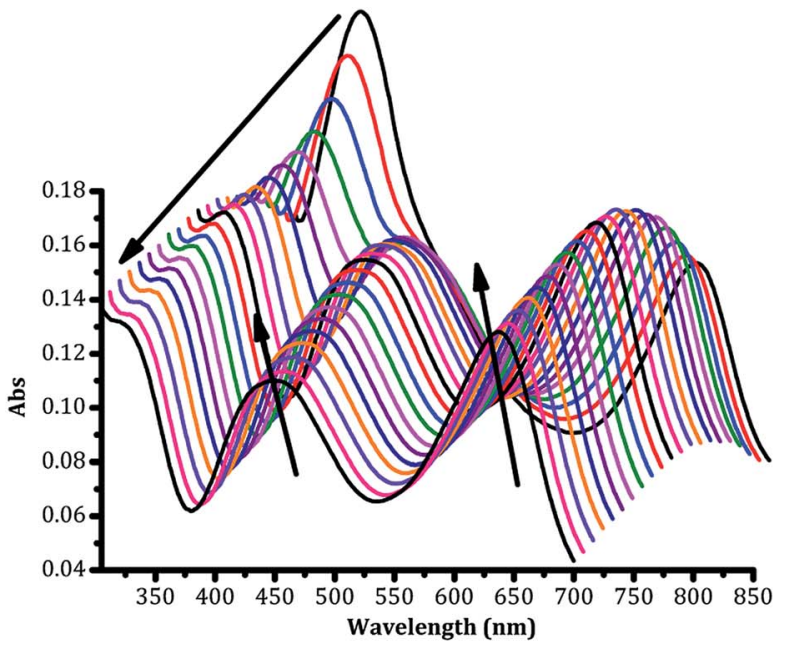

(b)

Fig. 7 UV-vis absorption spectra of $\mathrm{N}$ in DMSO- $\mathrm{H}_{2} \mathrm{O}\left(1 \times 10^{-5} \mathrm{M}\right)$ upon the molar additions ( $0-3$ equiv.) of (a) OH $\mathrm{OH}^{-}$, (b) A 3-D plot of the spectra.

indication that colorimetric activities of the sensor upon the addition of $\mathrm{CN}^{-}$are accompanied by electronic changes of the sensor, thereby affecting the HOMO and LUMO interactions significantly. Thus, $\mathbf{N}$ can be used as a "turn-on" fluorescence sensor for $\mathrm{CN}^{-}$detection in DMSO- $\mathrm{H}_{2} \mathrm{O}$. Moreover, it is strongly believed that the presence of the $-\mathrm{NO}_{2}$ electron withdrawing group (EWG) has some anti-fluorescence properties, thus weak emission intensity is observed on $\mathbf{N}$.

The stoichiometry investigation of sensor $\mathbf{N}$ and the selective anions, Job plots were produced for each anion. The solutions were prepared ranging from $10 \mathrm{ml}$ sensor : $0 \mathrm{ml}$ anion to $1 \mathrm{ml}$ sensor : $9 \mathrm{ml}$ anion and from these settings the Job's plots were obtained (Fig. 5), it the interaction ratios for $\mathrm{AcO}^{-}, \mathrm{OH}^{-}$and $\mathrm{F}^{-}$ were found to be $1: 1$ while that of $\mathrm{CN}^{-}$was $1: 2$.

\section{Computational calculations}

In order to further understand the electronic transitions, the structures of the uncomplexed (N) and complexed (NF) sensors in gas phases were calculated on DFT method [B3LYP/6-31G**] with Spartan'14. ${ }^{33-38}$ The calculations have indicated that there is a significant decrease in the energy gap (HOMO-LUMO) from the uncomplexed to complexed (Table 3). The decrease in energy gap is in agreement with the characteristics of the change in spectra of $\mathbf{N}$, upon complexing with $\mathrm{F}^{-}$, a bathochromic effect. Subsequently, the energy levels of both HOMO and LUMO have decreased upon the molar addition of $\mathrm{F}^{-}$to $\mathbf{N}$, with the LUMO decreasing more significantly than the HOMO, which is normally associated with a more stable set of orbitals

Table 2 Spectral data of $\mathrm{N}$ and interaction with $\mathrm{OH}^{-}$

\begin{tabular}{lllll}
\hline Sensor & $\lambda_{\max }$, abs peaks $(\mathrm{nm})$, without $\mathrm{OH}^{-}$ & $\varepsilon\left(\mathrm{M}^{-1} \mathrm{~cm}^{-1}\right)$ without $\mathrm{OH}^{-}$ & $\lambda_{\max }$, abs peaks (nm) $\left(\right.$ with $\left.\mathrm{OH}^{-}\right)$ & $\varepsilon\left(\mathrm{M}^{-1} \mathrm{~cm}^{-1}\right)$ with $\mathrm{OH}^{-}$ \\
\hline $\mathbf{N}$ & $356 ; 637$ & $18000 ; 8700$ & $319 ; 637$ & $13300 ; 13600$
\end{tabular}




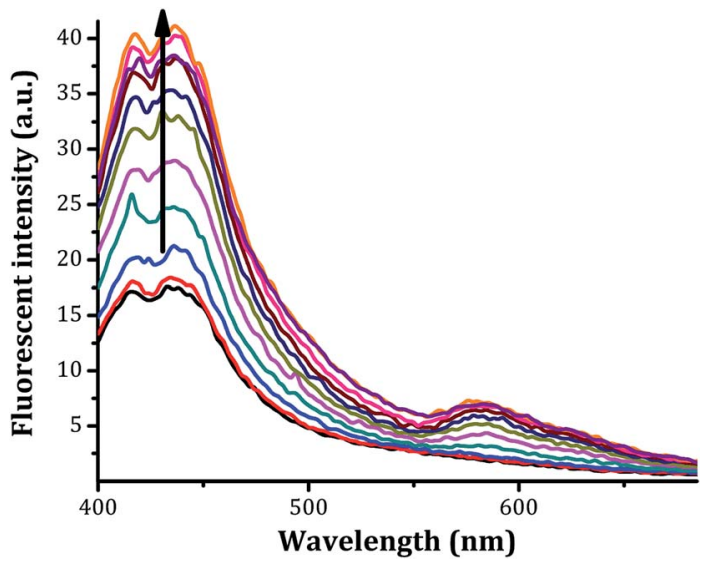

Fig. 8 Fluorescence spectra of $\mathrm{N}$ in DMSO $-\mathrm{H}_{2} \mathrm{O}\left(1 \times 10^{-5} \mathrm{M}\right)$ upon titration with $\mathrm{CN}^{-}(0-3$ equiv.).

Table 3 The summary of HOMO-LUMO orbitals and the energy gaps of $\mathrm{N}$ in the absence and presence of and $\mathrm{F}^{-}$

\begin{tabular}{lll}
\hline & $\mathbf{N}(\mathrm{eV})$ & $\mathbf{N F}(\mathrm{eV})$ \\
\hline LUMO & -3.17 & -7.09 \\
HOMO & -5.61 & -7.91 \\
Gap & $\mathbf{2 . 4 4}$ & $\mathbf{0 . 8 2}$
\end{tabular}

(LUMO). The chemical interaction of $\mathbf{N}$ with anions has resulted in structural distortion, for instance, upon complexing with $\mathrm{F}^{-}$ saw the structure shortens in length, from $180.180 \AA$ to $17.924 \AA$
$\left(\mathrm{N}_{5}\right.$ to $\left.\mathrm{N}_{6}\right)$, decreasing in length with $0.256 \AA$. Furthermore, the structure has also experienced angular distortion through $\mathrm{C}_{2} \mathrm{~N}_{3} \mathrm{~N}_{5}$ (or $\mathrm{C}_{5} \mathrm{~N}_{4} \mathrm{~N}_{6}$ ) of $146.39^{\circ}$ (Fig. 10) after the addition of $\mathrm{F}^{-}$, initially from $150.02^{\circ}$ of $\mathbf{N}$, signaling the hydrogen bonding interaction between the host $(\mathbf{N})$ and the guest $\left(\mathrm{F}^{-}\right)$. The Mulliken's atomic charge at the nitrogen of the $\mathrm{NH}$ group changed from -0.457 to -0.375 upon the NF adduct formation. Normally, the change of the negative environment is ascribed to the internal charge transfer (ICT) between the host and the guest, which is responsible for lowering down the HOMO-LUMO energy levels, through the stabilization of $\pi^{*}$ excited state of $\mathbf{N}$ by charge delocalization. The HOMO-LUMO gaps of NF have decreased (Fig. 9) and this translates the decrease in the molecular energy and thus stability of the complexed entity. Lowering of the HOMO-LUMO gap is responsible for absorption to be redshifted to longer wavelength and thus colorimetric activities are observed.

\section{Real sample analysis}

The effectiveness of sensor $\mathbf{N}$ towards anions, particularly $\mathrm{F}^{-}$, was further investigated by employing quantitative analysis using commercial toothpastes (two). The toothpaste sample solution was prepared as $20 \mathrm{mg} \mathrm{ml}^{-1}$ in $1 \mathrm{ml}$ of $\mathrm{H}_{2} \mathrm{O} .^{52}$ The toothpaste aqueous solution was added to $\mathbf{N}\left(1 \times 10^{-5} \mathrm{M}\right.$ in DMSO- $\mathrm{H}_{2} \mathrm{O}$ ) dropwise, resulting in color change from green to light blue (Fig. 11c), at ambient temperature. In addition, concomitant with the colour change, the UV-vis titrations of $\mathbf{N}$ with toothpastes generated parallel spectra, hinting to the presence of $\mathrm{F}^{-}$(Fig. 11a and b). Thus, $\mathbf{N}$ is highly selective and

LUMO
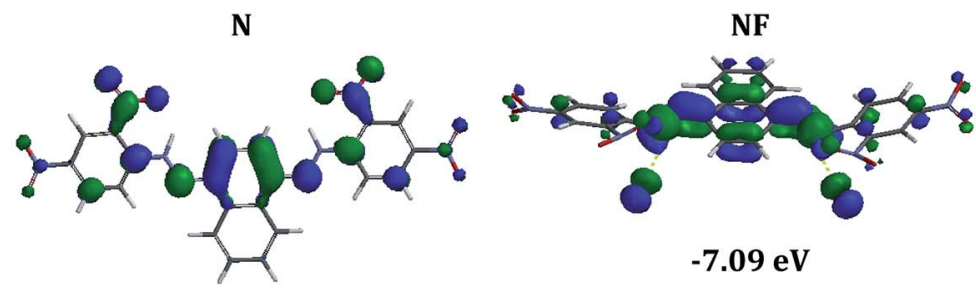

$-3.17 \mathrm{eV}$

HOMO
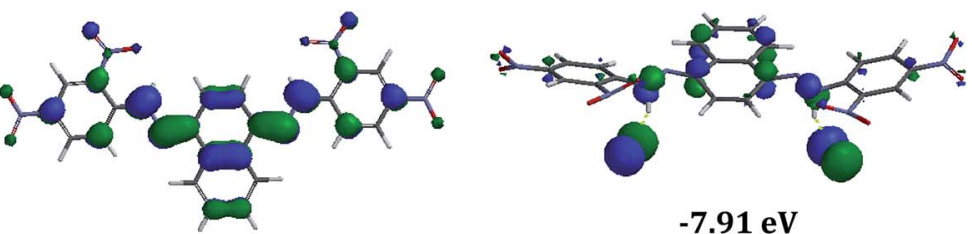

$-7.91 \mathrm{eV}$

$-5.61 \mathrm{eV}$

Optimized

structure

(HOMO-LUMO Gap)

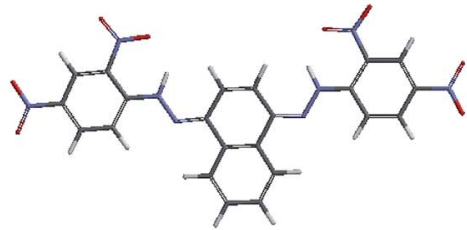

$(2.44 \mathrm{eV})$

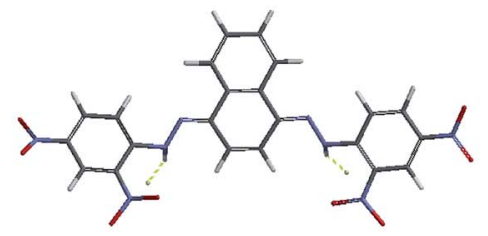

$(0.82 \mathrm{eV})$

Fig. $9 \mathrm{HOMO}$ and LUMO diagrams of $\mathrm{N}$ in the presence and absence of $\mathrm{F}^{-}$. 


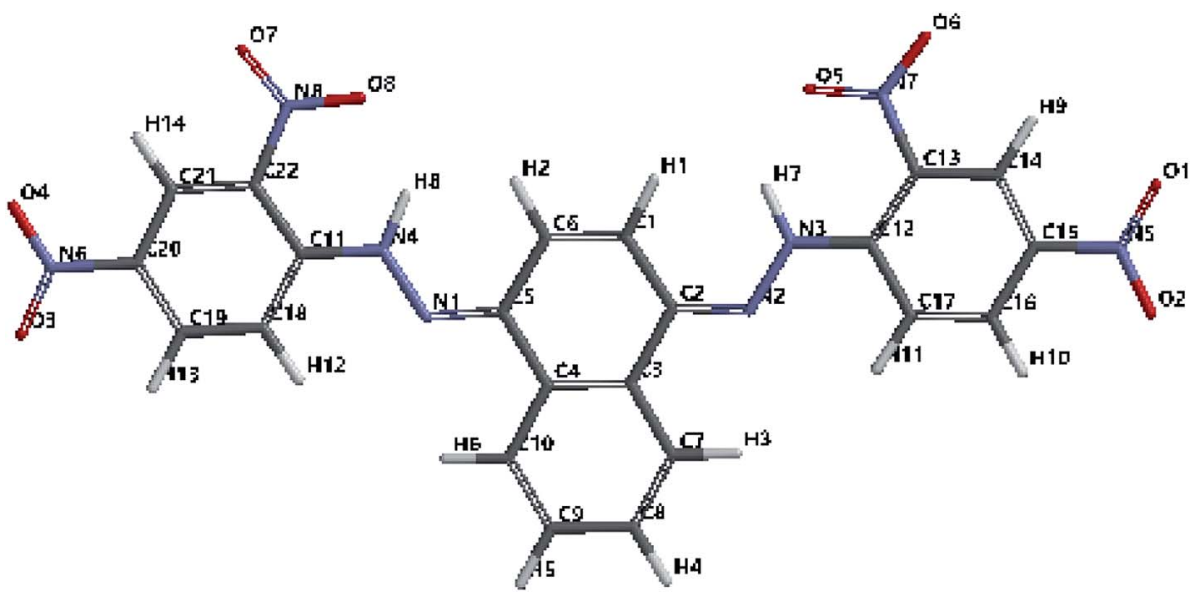

Fig. 10 Optimized structure showing the positions of atoms.

sensitive to $\mathrm{F}^{-}$, even when dissolved in water, which is very ideal in real time analysis.

In order to consolidate that $\mathrm{F}^{-}$was responsible for the observed spectral and colorimetric changes in the toothpastes
(Fig. 11a and b), three more titrations were carried out using different fluoride-containing counter ions $\left(\mathrm{NH}_{4} \mathrm{~F}, \mathrm{KF}\right.$ and $\left.\mathrm{CaF}_{2}\right)$, different from TBA, with spectra displayed (Fig. 12a-c). Upon the molar additions of fluoride containing solutions (each at

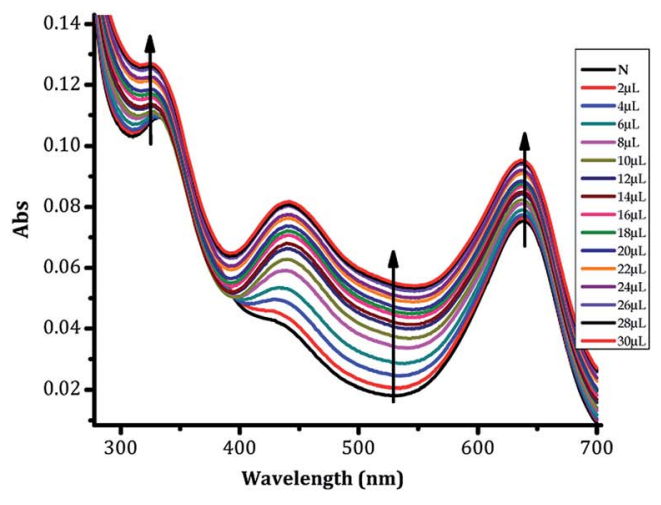

(a)

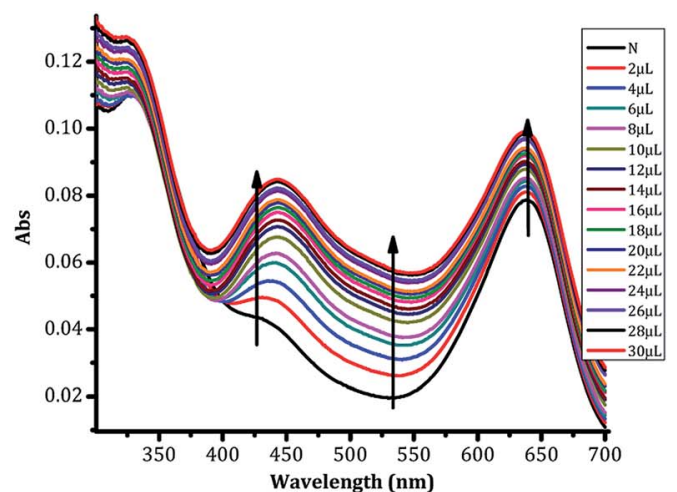

(b)

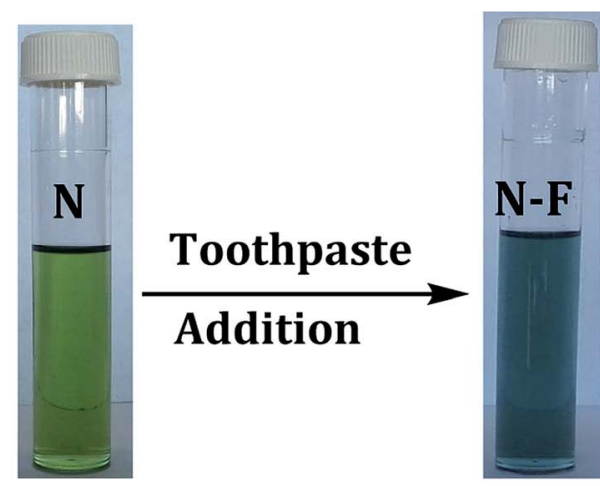

$\mathbf{N}$

$\mathbf{N}+$ Toothpaste

(c)

Fig. 11 UV-vis spectra of $\mathrm{N}\left(1 \times 10^{-5} \mathrm{M}\right)$ in DMSO- $\mathrm{H}_{2} \mathrm{O}$ with (a) Aquafresh, (b) Colgate, both dissolved in aqueous solutions and (c) visual colour change of $\mathrm{N}\left(1 \times 10^{-5} \mathrm{M}\right)$ upon addition of drops of toothpaste solution $\left(20 \mathrm{~g} \mathrm{ml}^{-1}\right)$ in $\mathrm{H}_{2} \mathrm{O}$. 


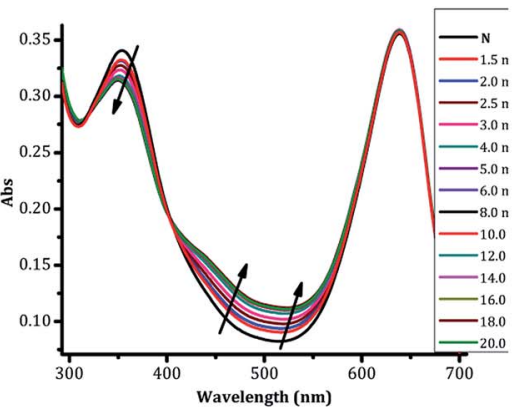

(a)

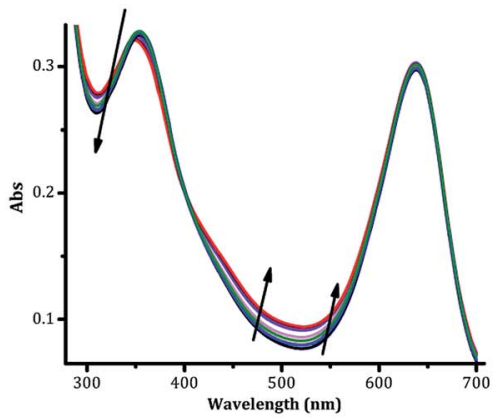

(b)

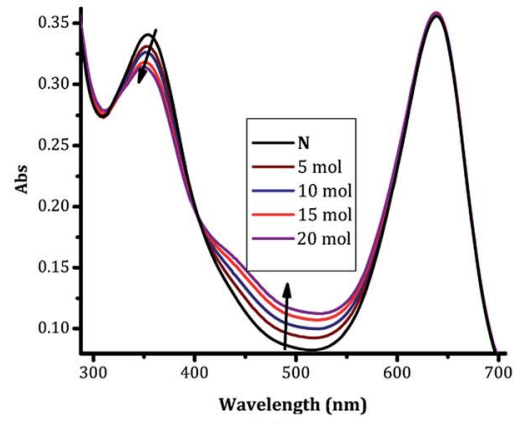

(c)

Fig. 12 UV-vis titration spectra of $\mathrm{N}\left(1 \times 10^{-5} \mathrm{M}\right)$ in $\mathrm{DMSO}-\mathrm{H}_{2} \mathrm{O}$ upon molar addition (0-20 equiv.) of, (a) $\mathrm{NH}_{4} \mathrm{~F}$, (b) $\mathrm{KF}$ and (c) CaF ${ }_{2}$, at ambient temperature.

a time) to $\mathbf{N}$, the spectra from the three graphs were characterized by the gradual decrease in absorption at $355 \mathrm{~nm}$, concomitant with an increase of the absorption band at $510 \mathrm{~nm}$. The isosbestic points were clearly visible at $405 \mathrm{~nm}$ in both cases, signaling the formation of the $\mathbf{N}-\mathbf{F}$ adjunct, upon the molar addition of $\mathrm{F}^{-}$to $\mathbf{N}$. These results were all in agreement with the spectra from the two toothpastes analyzed (Fig. 11a and b), as well as those of $\mathrm{F}^{-}$(Fig. 5b), which is evidently suggesting that the presence of fluoride is responsible for the spectral changes, rather than the counter ions TBA (Fig. 4b). Notingly, the molar additions of these solutions to $\mathbf{N}$ resulted in weaker interactions as displayed by spectra intensities, even when larger molar equivalents ( 20 equiv.) were used, the action suspectedly ascribed to the poor solubility of these compounds $\left(\mathrm{NH}_{4} \mathrm{~F}, \mathrm{KF}\right.$ and $\left.\mathrm{CaF}_{2}\right)$ in DMSO- $\mathrm{H}_{2} \mathrm{O}$, and also the high association constants of $\mathrm{F}^{-}$to these counter ions.

\section{Competitiveness studies}

In order to explore the possibilities of cross-detection of sensed anions by $\mathbf{N}$, competitive discrimination studies were carried out, in different sequences (Table 4). It is evident that $\mathrm{F}^{-}$was more associated with the sensor than any other sensed anion (Fig. 13), followed by $\mathrm{OH}^{-}$. Upon adding 5 equiv. of all anions listed in Fig. 13 in one cuvette (one after another), only $\mathrm{F}^{-}$and $\mathrm{OH}^{-}$persisted defying interferences from the other anions. This is in total agreement with the UV-vis titration behaviors of the two respective ions (Fig. 5a and 7a).

Furthermore, to study cross the detection behaviors of the sensed anions in the presence of $\mathbf{N}$ closely, competitive studies were carried out through addition of (sensed) anions added in different sequences (Table 4), in order to determine which of one of them stands out without distraction from others. Upon running out four different addition sequences in Table 2, it turned out that the discrimination patterns are dependent on which ion was added first and last. The spectrum displayed with high absorbance intensity is always the one added last in the sequence (Fig. 14a-d). This translates into the conclusion that, the first anion to be added is distracted by the subsequent following anions, and gets displaced by an immediate incoming anion, such that the characteristics of the last added anion dominates the spectra.

\section{Applications of $\mathbf{N}$ on test papers}

Testing paper strips were prepared from a printing paper which was dipped in $1 \times 10^{-3} \mathrm{M}$ solution of $\mathrm{N}$ in DMSO- $\mathrm{H}_{2} \mathrm{O}$ (Fig. 14) for 24 hours. The paper strips were left to dry for another 24 hours at room temperature. The $10 \mathrm{ml}$ solutions of $\mathrm{KCN}, \mathrm{NaOH}$, $\mathrm{KF}$ and $\mathrm{Zn}(\mathrm{AcO})_{2}\left(1 \times 10^{-3} \mathrm{M}\right)$ in tap water were prepared as a result (Fig. 15). The dry prepared test strip was dipped instantly ( 2 seconds at most), in each of the solutions, and allowed to dry on the white sheet of paper. Upon dipping the $\mathbf{N}$ soaked strips in each solution, the results showed that cyanide and hydroxide ions induced intense colour changes on the paper strips (Fig. 15), from original yellow to dark bluish $\left(\mathrm{CN}^{-}\right)$ and dark brownish $\left(\mathrm{OH}^{-}\right)$colours, instantaneously, detectable by naked eye. The colours of the litmus test papers may not be distinctively clear in the diagram, but cyanide (KCN) contaminated water gives a dark bluish colour, while hydroxide $(\mathrm{NaOH})$ gives a dark brownish colour, when the paper is wet. Thus the distinction can be distinctively observed when the paper strips are dipped and removed immediately, when wet. Moreover, for simplicity and real-time applications, the preparation of test papers was prepared on normal printing papers, just to highlight that this can be done on a very simple substrate, readily

Table 4 Addition sequences of competing anions to $\mathrm{N}$ (5 equiv. for each addition) in different orders in DMSO $-\mathrm{H}_{2} \mathrm{O}^{a}$

\section{Sequences}

$\begin{array}{ll}1 & \mathbf{N} \rightarrow \mathrm{F} \rightarrow \mathrm{AcO} \rightarrow \mathrm{CN} \rightarrow \mathrm{OH} \\ 2 & \mathbf{N} \rightarrow \mathrm{CN} \rightarrow \mathrm{AcO} \rightarrow \mathrm{OH} \rightarrow \mathrm{F} \\ 3 & \mathbf{N} \rightarrow \mathrm{OH} \rightarrow \mathrm{AcO} \rightarrow \mathrm{CN} \rightarrow \mathrm{F} \\ 4 & \mathbf{N} \rightarrow \mathrm{AcO} \rightarrow \mathrm{OH} \rightarrow \mathrm{F} \rightarrow \mathrm{CN} \\ { }^{a} \mathrm{~F}=\text { fluoride ion, } \mathrm{AcO}=\text { acetate ion, } \mathrm{CN}=\text { cyanide ion, } \mathrm{OH}=\text { hydroxide }\end{array}$
ion. 


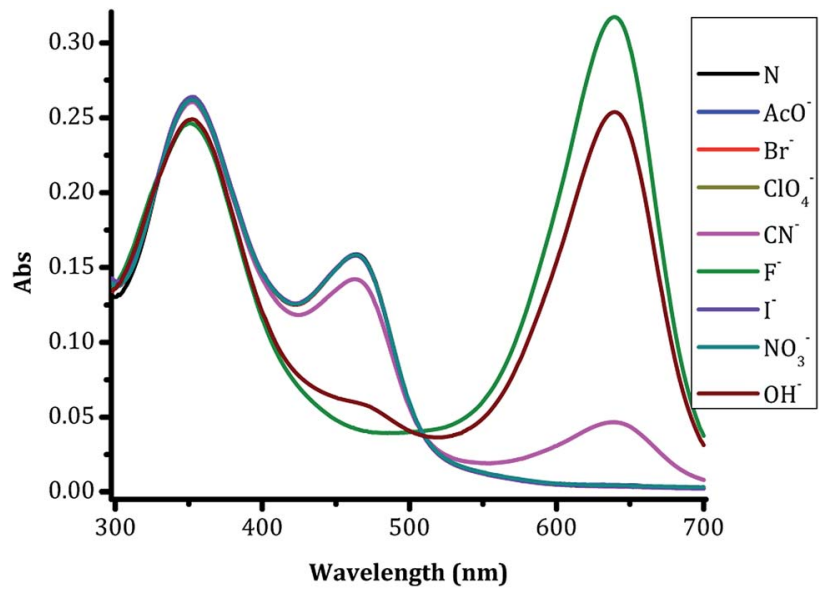

Fig. 13 The combined titrations of $\mathrm{N}\left(1 \times 10^{-5} \mathrm{M}\right)$ vs. anions (5 equiv.) in DMSO $-\mathrm{H}_{2} \mathrm{O}$ in different sequences.

available even in rural and remote areas. The resulting tests were all complementary in terms of the colorimetric effects on the test papers. However, the result from the test paper strips

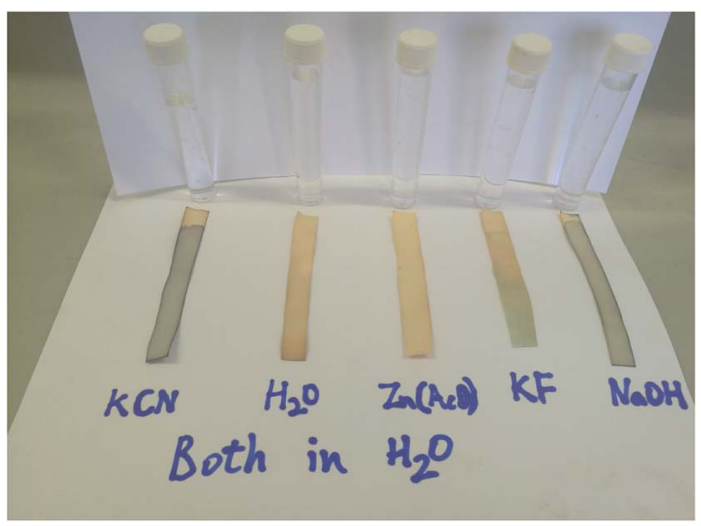

Fig. $15 \mathrm{~N}$-soaked testing litmus paper, immersed in tap water contaminated with different contaminants as indicated in the diagram.

were of high importance, that cyanide, in particular could be detected in aqueous solutions from ionic compound (e.g. common salts) sources.

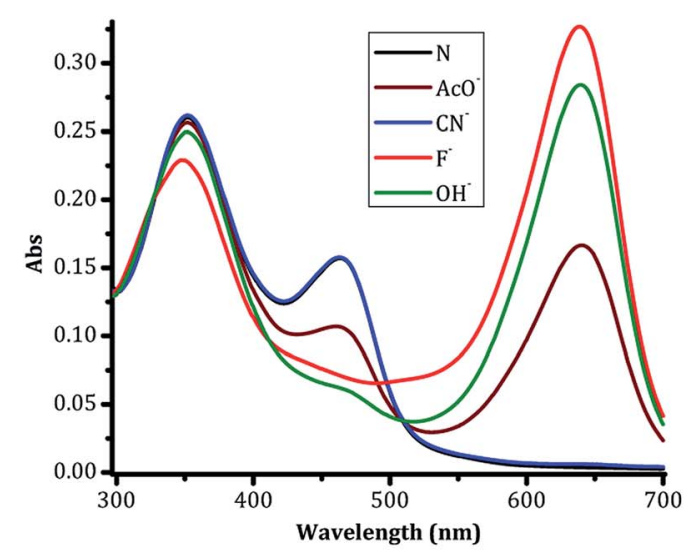

(b) Sequence 2

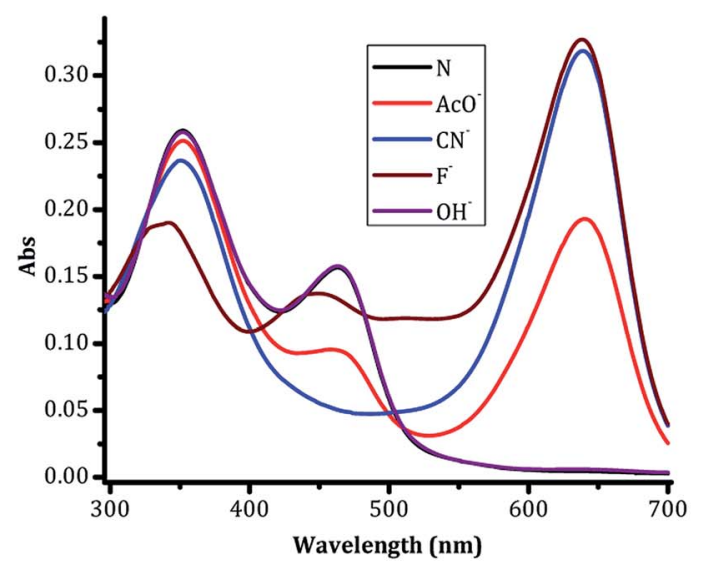

(c) Sequence 3

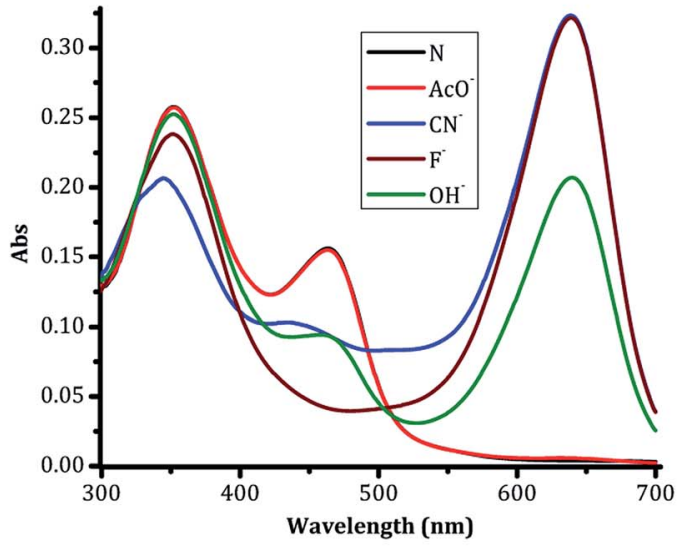

(d) Sequence 4

Fig. 14 The competitive nature of discriminated anions (5 equiv. each) added in four different sequences in DMSO- $\mathrm{H}_{2} \mathrm{O}$ at $1 \times 10^{-5} \mathrm{M}$ of $\mathrm{N}$. 


\section{Conclusion}

In summary, a highly stable sensitive chemosensor $\mathbf{N}$ was synthesized in a single step using Schiff base reaction and tested for sensitivity toward anions using the colorimetric sensor concept at a micro level in organic medium using water soluble DMSO- $\mathrm{H}_{2} \mathrm{O}$ mixture. Amongst all anions, $\mathbf{N}$ displayed a strong affinity of sensor towards $\mathrm{AcO}^{-}, \mathrm{F}^{-}, \mathrm{OH}^{-}$and $\mathrm{CN}^{-}$ions, as confirmed spectroscopically by UV-vis titration and naked eye observations; with a dramatic colour change from light green to light blue for $\mathrm{AcO}^{-}, \mathrm{F}^{-}$and $\mathrm{CN}^{-}$and a light green to violet/ purple for $\mathrm{OH}^{-}$. The mode of interactions of sensor $\mathbf{N}$ with anions was determined to be predominantly $1: 1$ for the three detectable anions and $1: 2$ for $\mathrm{CN}^{-}$using the job's plot method. The selectivity is greatly based on charge-charge interactions, and the involvement of the $\mathrm{N}-\mathrm{H}$ group's hydrogen bonds. The unique binding properties can have a greater utility in the development of new anion sensors with enhanced binding affinity and substrate specificity.

\section{Conflicts of interest}

There are no conflicts to declare.

\section{Acknowledgements}

This work was supported by the Research and Publication Unit (No. URPC/2014/153) of the University of Namibia, Namibia.

\section{References}

1 Q. Wu, L. Ma, Y. Xu, D. Cao, R. Guan, Z. Liu, et al., Two coumarin formhydrazide compounds as chemosensors for copper ions, Inorg. Chem. Commun., 2016, 69, 7-9.

2 O. Ozlem, Novel symmetric diimine-Schiff bases and asymmetric triimine-Schiff bases as chemosensors for the detection of various metal ions, J. Mol. Struct., 2016, 1125, 260-271.

3 F. Hu, M. Cao, J. Huang, Z. Chen, D. Wu, Z. Xu, et al., Sulfonamide and urea-based anions chemosensors, Dyes Pigm., 2015, 119, 108-115.

4 A. Ghosh, D. A. Jose and R. Kaushik, Anthraquinones as versatile colorimetric reagent for anions, Sens. Actuators, B, 2016, 229, 545-560.

5 Y. Zhang, D. Wang, C. Sun, H. Feng, D. Zhao and Y. Bi, A simple 2,6-diphenylpyridine-based fluorescence "turn-on" chemosensor for $\mathrm{Ag}^{+}$with a high luminescence quantum yield, Dyes Pigm., 2017, 141, 202-208.

6 J. Cheng, E. Yang, P. Ding, J. Tang, D. Zhang, Y. Zhao, et al., Two rhodamine based chemosensors for $\mathrm{Sn}^{4+}$ and the application in living cells, Sens. Actuators, B, 2015, 221, 688-693.

7 A. Mohammadi and S. Yaghoubi, A new dual colorimetric chemosensor based on quinazolinone for $\mathrm{CN}^{-}, \mathrm{AcO}^{-}$and $\mathrm{Cu}^{2+}$ ions, Sens. Actuators, B, 2017, 241, 1069-1075, DOI: 10.1016/j.snb.2016.10.034.
8 H. B. Kim, Y. Liu, D. Nam, Y. Li, S. Park, J. Yoon, et al., A new phosphorescent chemosensor bearing Zn-DPA sites for $\mathrm{H}_{2} \mathrm{PO}_{4}{ }^{-}$, Dyes Pigm., 2014, 106, 20-24.

9 G. Yu, Y. Cao, H. Liu, Q. Wu, Q. Hu, B. Jiang, et al., A spirobenzopyran-based multifunctional chemosensor for the chromogenic sensing of $\mathrm{Cu}^{2+}$ and fluorescent sensing of hydrazine with practical applications, Sens. Actuators, B, 2017, 245, 803-814.

10 S. Pangannaya, A. Kaur, M. Mohan, K. Raval, D. K. Chand and D. R. Trivedi, Synthesis and spectral investigation of colorimetric receptors for the dual detection of copper and acetate ions: application in molecular logic gates, Supramol. Chem., 2017, 29(8), 561-574.

11 W. Radchatawedchakoon, W. Sangsuwan, S. Kruanetr and U. Sakee, Synthesis and evaluation of simple naked-eye colorimetric chemosensors for anions based on azo dyethiosemicarbazones, Spectrochim. Acta, Part A, 2014, 121, 306-312.

12 V. Suryanti, M. Bhadbhade, D. S. Black and N. Kumar, Nacetylglyoxylic amide bearing a nitrophenyl group as anion receptors: NMR and X-ray investigations on anion binding and selectivity, J. Mol. Struct., 2017, 1146, 571-576.

13 A. S. F. Farinha, M. J. F. Calvete, F. A. A. Paz, A. C. Tomé, J. A. S. Cavaleiro, J. L. Sessler, et al., Octatosylaminophthalocyanine: a reusable chromogenic anion chemosensor, Sens. Actuators, B, 2014, 201, 387-394.

14 Y. Xu, Q. Yang, D. Cao, Z. Liu, S. Zhao, R. Guan, et al., A novel silicon-oxygen aurone derivative assisted by graphene oxide as fluorescence chemosensor for fluoride anions, Spectrochim. Acta, Part A, 2017, 182, 37-41.

15 Z. Luo, K. Yin, Z. Yu, M. Chen, Y. Li and J. Ren, A fluorescence turn-on chemosensor for hydrogen sulfate anion based on quinoline and naphthalimide, Spectrochim. Acta, Part A, 2016, 169, 38-44.

16 W. Wang, R. Li, T. Song, C. Zhang and Y. Zhao, Study on the fluorescent chemosensors based on a series of bis-Schiff bases for the detection of zinc(II), Spectrochim. Acta, Part A, 2016, 164, 133-138.

17 U. Yanar, B. Babür, D. Pekyilmaz, I. Yahaya, B. Aydiner, Y. Dede, et al., A fluorescent coumarin-thiophene hybrid as a ratiometric chemosensor for anions: synthesis, photophysics, anion sensing and orbital interactions, $J$. Mol. Struct., 2016, 1108, 269-277.

18 D. Udhayakumari and S. Velmathi, Naphthalene thiourea derivative based colorimetric and fluorescent dual chemosensor for $\mathrm{F}^{-}$and $\mathrm{Cu}^{2+} / \mathrm{Hg}^{2+}$ ions, Supramol. Chem., 2015, 27(7-8), 539-544.

19 L. K. Kumawat, N. Mergu, M. Asif and V. K. Gupta, Novel synthesized antipyrine derivative based "naked eye" colorimetric chemosensors for $\mathrm{Al}^{3+}$ and $\mathrm{Cr}^{3+}$, Sens. Actuators, B, 2016, 231, 847-859.

20 R. M. F. Batista, S. P. G. Costa and M. M. M. Raposo, Naphthyl-imidazo-anthraquinones as novel colorimetric and fluorimetric chemosensors for ion sensing, $J$ Photochem Photobiol A Chem, 2013, 259, 33-40.

21 Y. Hu, Y. Li, J. F. Joung, J. Yin, S. Park, J. Yoon, et al., Iridium complex bearing urea groups as a phosphorescent 
chemosensor for chiral anion recognition, Sens. Actuators, B, 2017, 241, 224-229.

22 J. H. Kim and S. H. Kim, Colorimetric polarity chemosensor based on a organometal halide perovskite functional dye, Dyes Pigm., 2016, 133, 73-78.

23 Y. M. Zhang, Q. Lin, T. B. Wei, D. D. Wang, H. Yao and Y. L. Wang, Simple colorimetric sensors with high selectivity for acetate and chloride in aqueous solution, Sens. Actuators, B, 2009, 137(2), 447-455.

24 H. Niu, Q. Shu, S. Jin, B. Li, J. Zhu, L. Li, et al., A simple ratiometric and colorimetric chemosensor for the selective detection of fluoride in DMSO buffered solution, Spectrochim. Acta, Part A, 2016, 153, 194-198.

25 S. Y. Li, D. B. Zhang, J. Y. Wang, R. M. Lu, C. H. Zheng and S. Z. Pu, A novel diarylethene-hydrazinopyridine-based probe for fluorescent detection of aluminum ion and naked-eye detection of hydroxide ion, Sens. Actuators, B, 2017, 245, 263-272.

26 V. Uahengo, Y. Zhang, B. Xiong, P. Zhao, P. Cai, L. Rhyman, et al., A Fluoro-Chromogenic Sensor Based on Organic Molecular Framework for $\mathrm{Cu}^{2+}$ and $\mathrm{F}^{-}$in Aqueous Soluble DMSO, J. Fluoresc., 2017, 27, 191-197.

27 M. Alkış, D. Pekyılmaz, E. Yalçın, B. Aydıner, Y. Dede and Z. Seferoglu, H-bond stabilization of a tautomeric coumarin-pyrazole-pyridine triad generates a PET driven, reversible and reusable fluorescent chemosensor for anion detection, Dyes Pigm., 2017, 141, 493-500.

28 Y. Jiang, L. L. Sun, G. Z. Ren, X. Niu and Z. Q. Hu, A novel colorimetric and fluorescent iminocoumarin-based chemosensor for acetate ion and its application to living cell imaging, Talanta, 2016, 146, 732-736.

29 X. Tian, X. Qi, X. Liu and Q. Zhang, Selective detection of picric acid by a fluorescent ionic liquid chemosensor, Sens. Actuators, B, 2016, 229, 520-527.

$30 \mathrm{~J}$. Li, C. Yin and F. Huo, Development of fluorescent zinc chemosensors based on various fluorophores and their applications in zinc recognition, Dyes Pigm., 2016, 131, 100-133.

31 H. Tavallali, G. Deilamy-Rad, A. Parhami and S. Lohrasbi, A novel and simple fluorescent and colorimetric primary chemosensor based on Congo-red for sulfite and resultant complex as secondary fluorescent chemosensor towards carbonate ions: fluorescent probe mimicking INHIBIT logic gate, Talanta, 2016, 149, 168-177.

32 P. R. Sharma, V. K. Soni, S. Pandey, G. Choudhary, A. K. Plappally and R. K. Sharma, Dipicrylhydrazine: a versatile visual anions sensor, J. Environ. Chem. Eng., 2017, 5(3), 2232-2239.

33 N. Maurya, S. Bhardwaj and A. K. Singh, A modest colorimetric chemosensor for investigation of $\mathrm{CN}^{-}$in semi-aqueous environment with high selectivity and sensitivity, Sens. Actuators, B, 2016, 229(2), 483-491, DOI: 10.1016/j.snb.2016.02.014.

34 G. J. Park, G. R. You, Y. W. Choi and C. Kim, A naked-eye chemosensor for simultaneous detection of iron and copper ions and its copper complex for colorimetric/ fluorescent sensing of cyanide, Sens. Actuators, B, 2016, 229, 257-271.

35 C. I. C. Esteves, M. M. M. Raposo and S. P. G. Costa, New 2,4,5-triarylimidazoles based on a phenylalanine core: synthesis, photophysical characterization and evaluation as fluorimetric chemosensors for ion recognition, Dyes Pigm., 2016, 134, 258-268.

36 Y. Shan, Z. Liu, D. Cao, G. Liu, R. Guan, N. Sun, et al., Coumarinic chalcone derivatives as chemosensors for cyanide anions and copper ions, Sens. Actuators, B, 2015, 221, 463-469.

37 L. M. Zimmermann, J. Nicolini, V. G. Marini and V. G. Machado, Anionic chromogenic chemosensors highly selective for cyanide based on the interaction of phenyl boronic acid and solvatochromic dyes, Sens. Actuators, B, 2015, 221, 644-652.

38 R. Jin, Theoretical study of chemosensors for fluoride anion and optical properties of the derivatives of organosilicon 1,8naphthalimide, J. Fluorine Chem., 2014, 162, 26-31.

39 M. Orojloo and S. Amani, Synthesis and studies of selective chemosensor for naked-eye detection of anions and cations based on a new Schiff-base derivative, Talanta, 2016, 159, 292-299.

40 A. D. Dubonosov, V. A. Bren, V. I. Minkin, E. N. Shepelenko, K. S. Tikhomirova, A. G. Starikov, et al., Photoswitchable dihetarylethene chemosensors for the selective "naked-eye" detection of fluoride anions, Tetrahedron, 2015, 71(46), 8817-8822.

$41 \mathrm{~K}$. Ponnuvel and V. Padmini, Turn-on fluorescence chemosensor for fluoride ions and its applicability in imaging of living cells, J. Lumin., 2016, 169, 289-294, DOI: 10.1016/j.jlumin.2015.09.027.

42 L. Wan, Q. Shu, J. Zhu, S. Jin, N. Li, X. Chen, et al., A new multifunctional Schiff-based chemosensor for mask-free fluorimetric and colorimetric sensing of $\mathrm{F}^{-}$and $\mathrm{CN}^{-}$, Talanta, 2016, 152, 39-44.

43 Y. Sun, J. H. Hu, J. Qi and J. B. Li, A highly selective colorimetric and "turn-on" fluorimetric chemosensor for detecting $\mathrm{CN}^{-}$based on unsymmetrical azine derivatives in aqueous media, Spectrochim. Acta, Part A, 2016, 167, 101-105, DOI: 10.1016/j.saa.2016.05.017.

44 L. Wang, W.-T. Li, W.-J. Qu, J.-X. Su, Q. Lin, T.-B. Wei, et al., A highly selective fluorescent chemosensor for successive detection of $\mathrm{Fe}^{3+}$ and $\mathrm{CN}^{-}$in pure water, Supramol. Chem., 2017, 29(7), 489-496.

45 Y. Shan, Z. Liu, D. Cao, Y. Sun, K. Wang and H. Chen, Nitro substituted chalcone derivatives as quick-response chemosensors for cyanide anions, Sens. Actuators, B, 2014, 198, 15-19.

46 J. M. M. Rodrigues, A. A. S. Farinha, A. C. Tomé, J. A. S. Cavaleiro and J. P. C. Tomé, Highly selective optical chemosensor for cyanide in aqueous medium, Sens. Actuators, B, 2016, 224, 81-87.

47 Z. M. Dong, W. Wang, Y. B. Wang, J. N. Wang, L. Y. Qin and Y. Wang, A reversible colorimetric chemosensor for "Naked Eye" sensing of cyanide ion in semi-aqueous solution, Inorg. Chim. Acta, 2017, 461, 8-14. 
48 J. G. Laitos, Cyanide, Mining, and the Environment, Pace Envtl. L. Rev., 2013, 30(3), 869-949; http:// digitalcommons.pace.edu/pelr/vol30/iss3/2.

49 V. Uahengo, B. Xiong, N. Zhou, P. Cai, K. Hu and G. Cheng, Synthesis of a phenylhydrazone-based colorimetric anion sensor with complementary IMP/INH logic functions, Chin. J. Chem., 2012, 30(8), 1702-1708.

50 V. Uahengo, B. Xiong, P. Zhao, Y. Zhang, P. Cai, K. Hu, et al., Three-channel ferrocene-based chemosensors for $\mathrm{Cu}$ (II) and
$\mathrm{Hg}$ (II) in aqueous environments, Sens. Actuators, B, 2014, 190, 937-945, DOI: 10.1016/j.snb.2013.09.039.

51 V. Uahengo, P. Cai and L. S. Daniel, A BTT-Based Colorimetric Dual Sensor for $\mathrm{Hg}$ (II) and Selected Anions with Molecular Logic Operations, Adv. Chem., 2016, 2016, 6438187.

52 S. Suganya, J. S. Park and S. Velmathi, Visual sensing of aqueous anions by $\mathrm{C} 2$-symmetric chemosensor and its application in real sample analysis, Sens. Actuators, B, 2014, 190, 679-684. 